\title{
Dimensions of learning organization: Implications for human resources effectiveness in commercial banks
}

\author{
Sulaiman Olusegun Atiku ${ }^{a^{*}}$, Godwin Kaisara ${ }^{a}$, Stewart Kaupa ${ }^{a}$ and Hylton Villet ${ }^{a}$
}

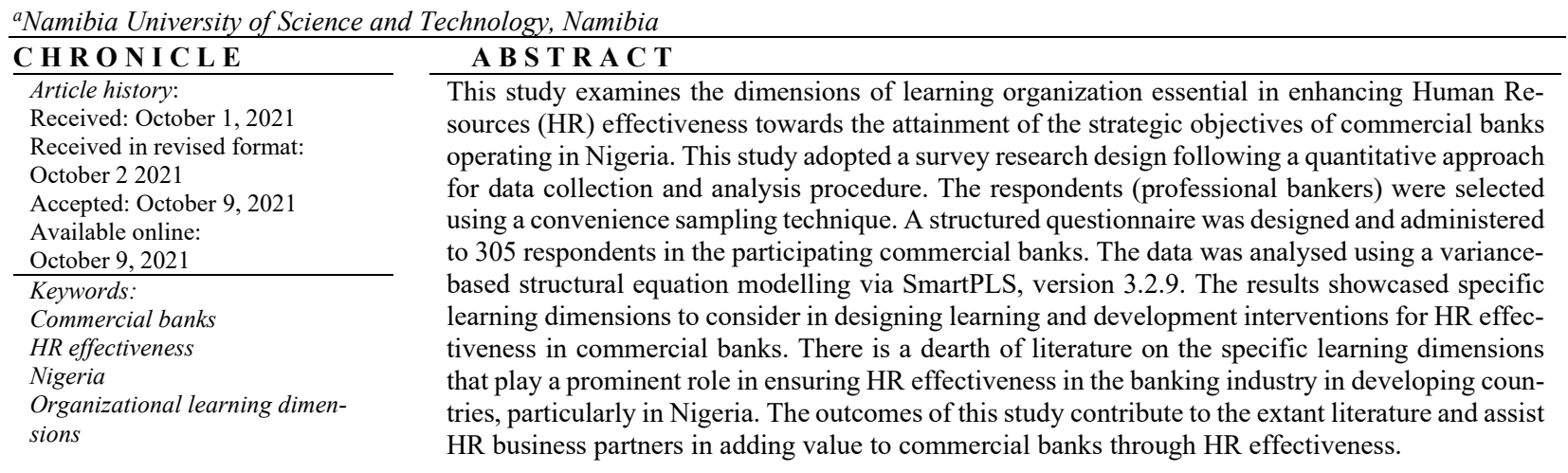

(C) 2022 by the authors; licensee Growing Science, Canada

\section{Introduction}

Learning agility is key for effective banking operations to remain competitive in the global business environment. Learning and development strategies at various levels and business units in commercial banks remain one of the key human resource management interventions in enhancing HR effectiveness for sustainable competitive advantage in the digital age. Learning and development interventions in commercial banks help in upskilling employees based on the vast technical innovations incorporated into their electronic banking operations. Furthermore, learning and development play a prominent role in providing professional knowledge such as cognitive knowledge (know-what), advanced skills (know-how), systems understanding (know-why), and self-motivated creativity (care-why) in commercial banks (Jamal \& Tilchin, 2016). The development of such professional knowledge at various levels in banks is important for HR effectiveness, excellent service delivery, total customer satisfaction and competitive advantage.

Professional knowledge can be developed at the individual level, team level and organizational level, which are the dimensions of the learning organization (Marsick \& Watkins, 2003). A popular and seminal tool used to measure the aforementioned dimensions is the Dimensions of Learning Organization Questionnaire (DLOQ). Despite the use of the DLOQ by researchers in many organizations across the globe, little is known about the influence of the learning organization on HR effectiveness in the Nigerian banking industry (Atiku et al., 2014). Furthermore, there is limited literature on the specific organizational learning dimension that plays the most prominent role in ensuring HR effectiveness in commercial banks operating in Nigeria. Hence, this study examines the dimensions of learning organization essential in enhancing HR effectiveness towards attaining the strategic objectives of commercial banks operating in Nigeria.

\footnotetext{
* Corresponding author.

E-mail address: olusegunatiku@gmail.com (S. O. Atiku)

(C) 2022 by the authors; licensee Growing Science, Canada doi: $10.5267 /$ j.msl.2021.10.002
} 


\section{Literature review}

\subsection{Dimensions of Learning Organization}

The increase in globalization, catalyzed by the supranational entities that transcend national and regional borders, has led to an ever-evolving and competitive market space. To stay competitive, organizations are forced to adapt through unlearning old habits and learning new habits. The modern organization which exudes such characteristics is known as the "learning organization". The concept of the learning organization has gained prominence in literature and continues to receive increasing attention in various management fields. This is because organizational learning cultivates and provides an environment that is conducive to learn new skills and knowledge sharing at various levels within a system (Alavi et al., 2014). The basis of the learning organization is the creation, retention and transmission of knowledge within the organization to manage change for a sustained competitive advantage (Borisov \& Stamenkova, 2020). Contemporary business executives are especially keen to embrace the concept of the learning organization and implement its principles as a source of competitive advantage (Rupčić, 2020). The learning organization could inspire humanity to remain on track, because "every attempt to regulate organic systems according to some model proved to be short-lived...even though general guidelines are identifiable and clear, it is impossible to completely dismantle the black box and deprive it of its charms of constant creation" (Rupčić, 2020, p. 27). Scholars have identified and popularized three organizational learning dimensions, namely, individual learning, team learning and organizational learning (Marsick \& Watkins, 2003).

\subsubsection{Individual learning}

Individual learning is a vital organizational process that encapsulates the creation, acquisition and knowledge sharing to institutionalize dynamic business conditions (Atiku \& Fields, 2018; Sadq, Othman, \& Mohammed, 2020). Organizations could promote individual learning by purposively cultivating organizational learning processes that prioritize individual learning. Nevertheless, Abenga (2018) argues that although individual learning is essential to the sustainability of organizations, it is not sufficient for organizational learning to take place. Such sentiments are echoed by Senge (2006), who argues that individual learning does not automatically translate into teams and organizational learning. Rather, Senge (2006) argues that individual knowledge must be incubated to effectively morph into teams leading organizational development. Investment in individual learning develops human capital within the organization. Consequently, the enhancement of individuals' skills, knowledge and abilities positively influence the team's effectiveness and organizational performance. Human capital development at the individual level is critical in enhancing workforce creativity to improve the product and/or service innovation of an organization (Haris et al., 2019). Accordingly, a higher salary package and job security are some of the benefits of human capital development to an individual employee. Human capital is a product of individual learning, which leads to increased efficiency and profitability in service-oriented organizations (Haris et al., 2019). Human capital has been labeled as being extremely important because employee capabilities are reflected through organizational performance (Abualoush et al., 2018).

\subsubsection{Team learning}

Whilst the learning organization makes room for and nurtures individual talent, individual talents are viewed as building blocks necessary for the betterment of the whole team (Mthombeni \& Niemand, 2019). Teams have become omnipresent in contemporary organizations, and team learning has become integral to the effective functioning of such teams (Watzek et al., 2019). Team learning fosters workforce creativity and prepares organizations to be agile and responsive in an increasingly dynamic corporate space (Pandey et al., 2019). For team learning to effectively occur, several facilitating social conditions must be in place. There is a need for cultural values that support knowledge sharing through coaching or mentoring (Galeazzo \& Furlan, 2019; Islamy, Yuniarsih, Ahman, \& Kusnendi, 2020; Sadq et al., 2020; Werner \& Dickson, 2018), sound interpersonal relationships for effective collaboration (Schiavoni, de Faria, \& Manzolli, 2019) and excellent team leadership behavior (Bednall, et al., 2020; Koeslag-Kreunen et al., 2018; Raes et al., 2013; Schaubroeck, Carmeli, Bhatia, \& Paz). Furthermore, Raes et al., (2017) note that a certain degree of maturity might be needed for teams to share information freely, learn from diverse views and express disagreements. In a study conducted among first-year students enrolled for a Master's degree programme in Educational Science or Business Administration in Germany, Watzek et al. (2019) established that team learning (e.g. sharing) is also facilitated by positive social-emotional reactions (such as agreement). Team leadership behavior such as transformational and innovative leadership facilitate team learning behavior and collaboration in business organizations (Afsar \& Umrani, 2019; Bednall, et al., 2020; Koeslag-Kreunen et al., 2018).

\subsubsection{Organizational learning}

Organizational learning is often depicted by two key modes of learning, that is, adaptive learning and experiential learning (Zuo et al., 2019). Both modes of learning are key to the cultivation of a culture of innovation within an organization. One of the facets of organizational learning is the prevalence of knowledge sharing throughout the organization. The dissemination of knowledge is beneficial to the development of knowledgeable staff, who are a critical aspect of initiatives that seek to 
develop an agile organization (Alavi et al., 2014; Tahernezhad, Sadaghiani, \& Ghaiyoomi, 2013). Agility and effectiveness in service provision subsequently influence the brand image that consumers have of a given organization.

According to Alavi et al. (2014), the structure of an organization has a significant influence on workforce creativity and organizational learning. The authors posit that a flat organizational structure is helpful as less hierarchies encourage more interactions amongst staff members. Furthermore, a decentralized structure cultivates greater autonomy and shared responsibilities at different organizational levels. Nevertheless, Alavi et al. (2014) also note that flat structures may negatively impact the motivation to learn, as there would be limited growth opportunities to strive towards within the organization. Consequently, in the absence of a hierarchical structure, managers need to ensure that other incentives are provided to encourage organizational learning. Organizational learning may also be enhanced through talent retention (Atiku \& Fields, 2018; Tan \& Olaore, 2021).) Findings show that when employees spend an extended period within a learning organization, they become cultured in its knowledge sharing practices (Tan \& Olaore, 2021).

\subsection{Learning Organization and Human Resource Effectiveness}

The three main antecedents to HR effectiveness are HR practices or interventions, the effective implementation of practices and HR metrics (Guest \& Conway, 2011). HR interventions include performance management, training and development interventions, managing workforce diversity and wellness, flexible work arrangements (flexibility) or work-life balance strategy and talent management (Armstrong, 2020). Therefore, HR effectiveness is dependent on the execution of these interventions coupled with a valid metric to assess its contributions to organizational goals. Specifically, this study examines the contributions of learning and development interventions at the individual, team and organizational levels to HR effectiveness in commercial banks.

A myriad of studies has attempted to establish the link between the learning organization and HR effectiveness (Islam \& Tariq, 2018; Tan \& Olaore, 2021). For example, Islam and Tariq (2018) establish that a learning organization enhances employee work engagement, "which ultimately promotes sharing of knowledge, creativity and proactivity of the employees" in the service industry (Haris et al., 2019, p. 265). Using a commercial bank as a case study, Tan and Olaore (2021) echo the findings of Islam and Tariq (2018), whose study established a significant relationship between organizational learning and HR effectiveness and productivity. Tan and Olaore (2021) found that the impact of organizational learning is not confined to a particular organizational level, rather its impact encompasses lower, middle and top management positions through enhanced workforce productivity within an organization. The conceptual model used in showcasing the relationship between dimensions of learning organization and HR effectiveness in commercial banks is illustrated in Figure 1.

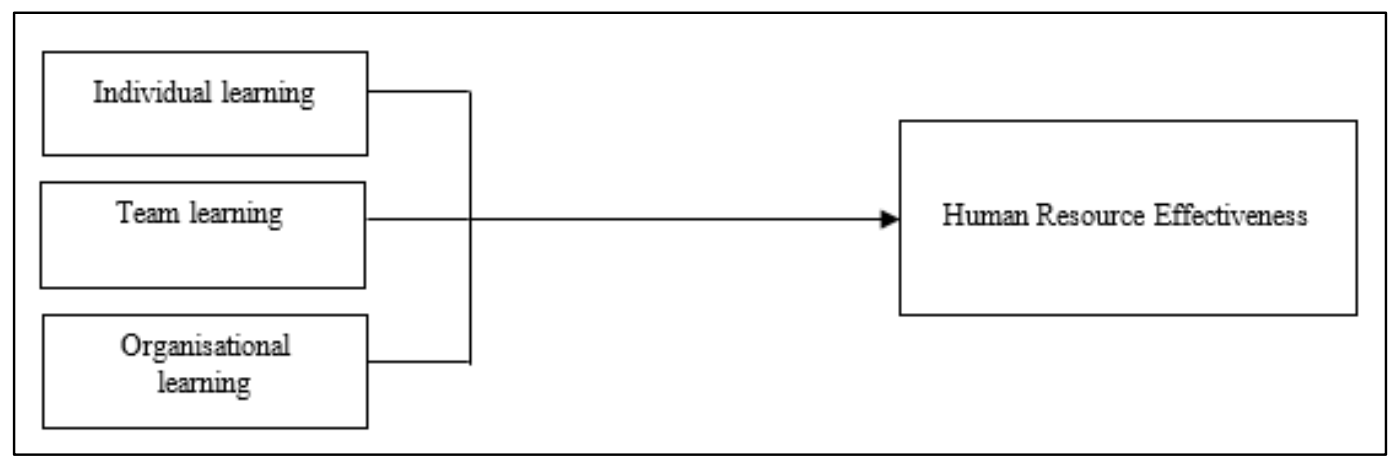

Fig. 1. Conceptual model on the dimensions of learning organization and HR effectiveness Source: Own compilation

Based on the literature and constructs operationalized through the conceptual model illustrated in Figure 1, this study hypothesized as follows.

Hypothesis 1: Individual learning exerts a significant influence on HR effectiveness in commercial banks. Hypothesis 2: Team learning has a significant influence on HR effectiveness in commercial banks.

Hypothesis 3: Organizational learning exerts a significant effect on HR effectiveness in commercial banks.

\section{Methods}

This study adopted a cross-sectional survey research design to examine the effects of organizational learning dimensions on HR effectiveness in commercial banks. A quantitative approach was adopted for data collection and analysis procedure to objectively showcase the influence of organizational learning dimensions on HR effectiveness using path analysis. 


\subsection{Participants}

The respondents were professional bankers working in the Nigerian banking industry. A structured questionnaire was designed and administered to 305 respondents in the participating commercial banks. Respondents were selected using a convenient sampling technique in line with the ethical guidelines for social science research.

\subsection{Measures}

The three dimensions of learning in commercial banks were measured in this study using DLOQ adapted from Watkins and Marsick (2003). The scale contains 16 items designed on a 4-point Likert-type rating scale ranging from 1 (strongly disagree) to 4 (strongly agree). The first dimension contains 5 items measuring learning at individual level. The second dimension contains 5 items measuring learning at team level. And the third dimension contains 6 items measuring learning at organizational level. On the other hand, we measured HR effectiveness using a scale adapted from Katou and Budhwar (2010). The scale contains 6 items measuring HR effectiveness in commercial banks, rated on a 5-point Likert-type scale ranging from 1 (very ineffective) to 5 (very effective).

\subsection{Statistical analysis}

The quantitative data collected in this study was analyzed using a variance-based structural equation modelling via SmartPLS, version 3.3.3 for path analysis (Ringle, Wende, \& Becker, 2015). SmartPLS is instrumental in showcasing the path analysis from each explanatory (exogenous) variable to the dependent (endogenous) variable. The exogenous variables provided in the structural model are individual, team and organizational learning dimensions. The endogenous variable was specified as HR effectiveness in commercial banks.

\section{Results and Discussion}

The preliminary data analysis procedure was used to ascertain the validity of the instrument using average variance extracted (AVE) for convergent validity and Fornell-Larcker criterion for discriminant validity. Three items (IL2, OL11 and OL12) were deleted to obtain acceptable AVE in this study. As indicated in Table 1, the AVE values for HR effectiveness (0.656), Individual learning $(0.557)$, team learning $(0.510)$ and organizational learning $(0.542)$ are greater than the threshold of 0.5 , which is an indication of convergent validity of the latent variables. The square root values of AVE for HR effectiveness $(0.810)$, Individual learning $(0.746)$, team learning $(0.714)$ and organizational learning $(0.737)$ are greater than the inter-item correlations, which ascertain discriminant validity following the Fornell-Larcker criterion. Statistically, the Cronbach's alpha and composite reliability coefficients of all latent variables investigated in this study are greater than 0.7 , which confirm the internal consistency of the research instrument.

Table 1

Construct reliability and validity

\begin{tabular}{llllcccc}
\hline Construct & A & CR & AVE & HRE & IL & TL & OL \\
\hline HR effectiveness (HRE) & 0.895 & 0.920 & 0.656 & $\mathbf{0 . 8 1 0}$ & & & \\
Individual learning (IL) & 0.764 & 0.833 & 0.557 & 0.266 & $\mathbf{0 . 7 4 6}$ & & \\
Team learning (TL) & 0.779 & 0.836 & 0.510 & 0.351 & 0.710 & $\mathbf{0 . 7 1 4}$ & \\
organizational learning (OL) & 0.721 & 0.825 & 0.542 & 0.343 & 0.512 & 0.587 & $\mathbf{0 . 7 3 7}$ \\
\hline
\end{tabular}

Note. All correlations are significant at $(\mathrm{p}<0.001), \alpha=$ Cronbach's alpha, $\mathrm{CR}=$ composite reliability, AVE $=$ average variance extracted; diagonal are the square roots of the AVE.

The structural model showcasing the influence of dimensions of learning organization on HR effectiveness in commercial banks is presented in Figure 2. The path coefficient from individual learning to HR effectiveness $(r=-0.005, p>0.05, n=$ 305) shows that individual learning exerts no significant positive effect on HR effectiveness. The path from team learning to HR effectiveness $(\mathrm{r}=0.232, \mathrm{p}<0.001, \mathrm{n}=305)$ implies that team learning exerts a significant direct effect on HR effectiveness in commercial banks. Finally, the path coefficient from organizational learning to HR effectiveness $(r=0.209, p<0.01, n=$ 305 ) shows that organizational learning exerts a significant positive effect on HR effectiveness in commercial banks. The $\mathrm{R}^{2}$ value $\left(R^{2}=0.152\right)$ explains the influence of learning dimensions on HR effectiveness in commercial banks. The $R^{2}$ value suggests that the predictive variables examined in this study explain $15.2 \%$ of the variance in HR effectiveness in the Nigerian commercial banks. 


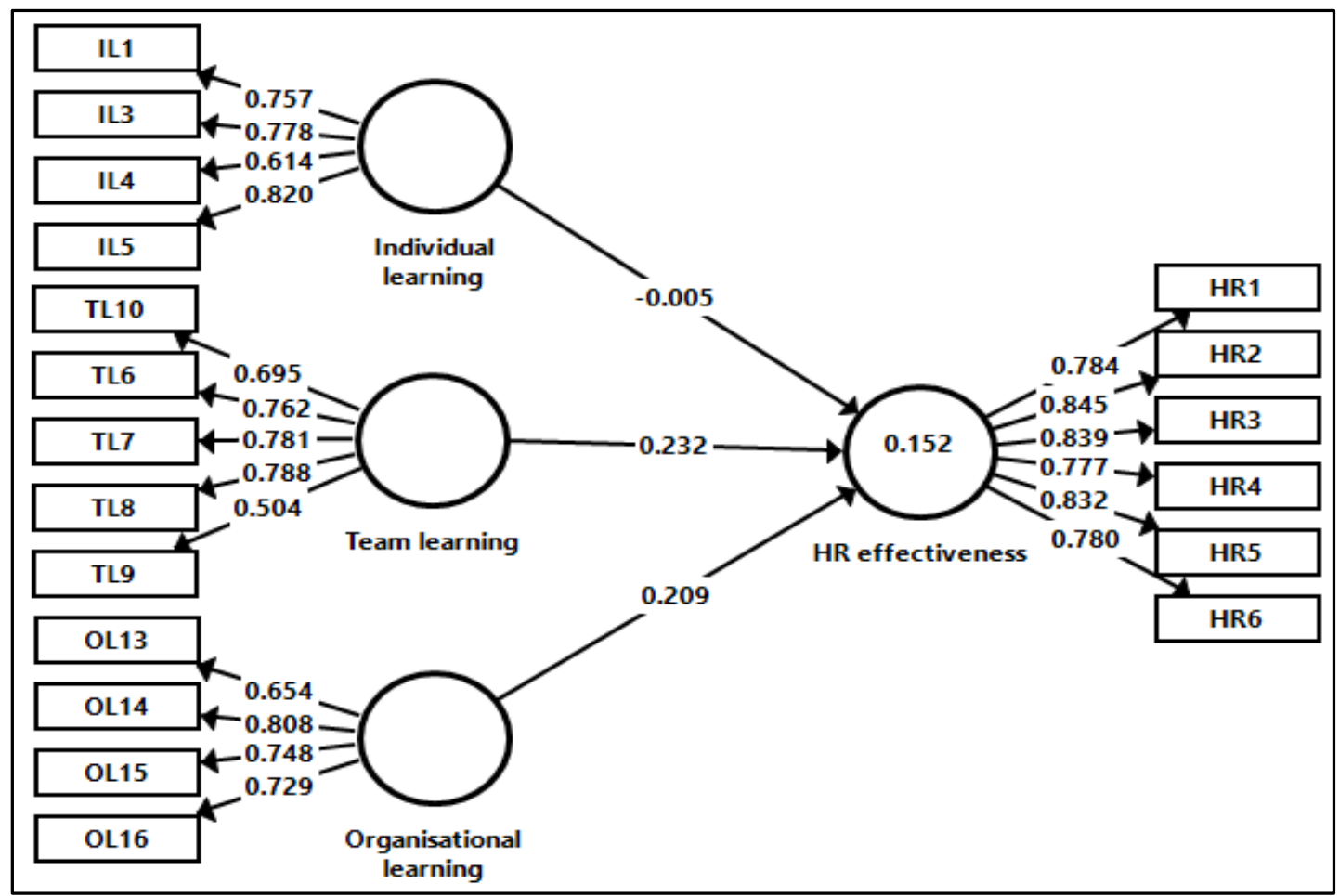

Fig. 2. Learning dimensions and HR effectiveness

Table 2 provides a summary of findings from the structural model explaining the significant influence of each dimension of learning organization on HR effectiveness in commercial banks. Statistically, hypothesis 1 was rejected judging from the beta loading and the corresponding level of significance. By implication, individual learning exerts no significant influence on HR effectiveness of commercial banks operating in Lagos, Nigeria. Hypotheses 2 and 3 were accepted, which indicate that learning at team and organizational levels exert a significant influence on HR effectiveness in commercial banks. Team learning made the largest contributions to HR effectiveness in commercial banks; judging from the beta loading and the p-value reported in Table 2. This result corroborates Mthombeni and Niemand's (2019) research outcomes based on the need for functional learning and development across business units in financial institutions.

Table 2

Summary of findings from the hypotheses

\begin{tabular}{clcc}
\hline Hypothesis & Latent variable & Beta loading & Decision \\
\hline H1 & Individual learning exerts a significant influence on HR ef- & $\mathrm{r}=-0.005$ & $\mathrm{p}>0.05$, \\
& fectiveness in commercial banks & $\mathrm{n}=305$ & Rejected \\
& & $\mathrm{r}=0.232$ & Accepted \\
$\mathrm{H} 2$ & Team learning has a significant influence on HR effective- & $\mathrm{p}<0.001$ & $\mathrm{n}=305$ \\
& ness in commercial banks. & $\mathrm{r}=0.209$ & Accepted \\
& & $\mathrm{p}<0.01$ & $\mathrm{n}=305$ \\
\end{tabular}

\subsection{Practical implications}

The implication of findings from this study for HR business partners in commercial banks is that learning at team level makes the most significant contributions to HR effectiveness, judging from the beta loadings and the $\mathrm{p}$ values reported. This means that learning and development interventions for specific business units are more effective in enhancing HR outcomes than learning at individual level. Collective intelligence, which is required in developing new products and services in the world of work, could be enhanced through team learning. If team learning is properly integrated and implemented by HR practitioners and team leaders, it is more effective in enhancing collective creativity and business units' performance, thereby contributing to the sustainable competitive advantage of an organization. For example, specific learning and development programmes for the customer service unit, marketing and sales department, information and technology services, human resources and others will have a big impact on those business units compared to individual learning. 
The next learning dimension in terms of contributions to HR effectiveness in commercial banks is learning at organizational level. The practical implication of this is that HR outcomes could be enhanced when an organization encourages people to collaborate across the organization when solving business problems. This can thrive when a knowledge sharing culture is held by organizational members. The use of corporate universities by learning and development units is instrumental in providing training opportunities to employees based on data collected from the training needs assessment. Therefore, investment in learning and development at organizational level is effective in enhancing HR effectiveness in commercial banks.

Conversely, learning at individual level made no significant contribution to HR effectiveness in commercial banks. The managerial implication of this result revolves around the need for a proper alignment of self-development opportunities and the strategic objectives of the banks. Career advancement opportunities and talent retention strategies could be integrated to ensure that learning and development at individual level add value to HR effectiveness in the banking industry.

\section{Conclusion}

This study examined the dimensions of the learning organization essential in enhancing HR effectiveness in commercial banks. Based on the results, this study concludes that learning at team level plays a critical role in enhancing HR effectiveness in the banking industry. Therefore, team learning is essential for horizontal alignment of strategic objectives and enhancing business units' performance, culminating in HR effectiveness in the banking industry. The limitation of this study has to do with use of the convenience sampling technique following the ethical guidelines in social science research. Therefore future research may adopt other sampling techniques to provide a robust generalization of the key findings.

\section{References}

Abenga, E. S. B. (2018). Applicability of the learning organization idea to universities in Kenya. Educational Research and Reviews, 13(23), 745-753. https://doi.org/10.5897/err2018.3607

Abualoush, S., Masa'deh, R., Bataineh, K., \& Alrowwad, A. (2018). The Role of Knowledge Management Process and Intellectual Capital as Intermediary Variable Between Knowledge Management. Interdisciplinary Journal of Information, Knowledge, and Management, 13, 279-309.

Afsar, B., \& Umrani, W. A. (2019). Transformational leadership and innovative work behavior: The role of motivation to learn, task complexity and innovation climate. European Journal of Innovation Management, 23(3), 402-428.

Alavi, S., Abd. Wahab, D., Muhamad, N., \& Arbab Shirani, B. (2014). Organic structure and organizational learning as the main antecedents of workforce agility. International Journal of Production Research, 52(21), 6273-6295. https://doi.org/10.1080/00207543.2014.919420

Armstrong, M. (2020). Human resource management practice. Kogan Page Limited.

Atiku, S. O., \& Fields, Z. (2018). Organizational Learning Dimensions and Talent Retention Strategies for the Service Industries. In Disruptive Technology: Concepts, Methodologies, Tools, and Applications (pp. 1145-1168). IGI Global. https://doi.org/10.4018/978-1-5225-9273-0.ch056

Atiku, S. O., Chitakunye, P. \& Fields, Z. (2014). Influence of Organizational Learning and Human Resource Outcomes on Commercial Banks' Performance in Nigeria. Journal of Social Sciences, 40(1), pp. 9-20.

Bednall, T. C., E. Rafferty, A., Shipton, H., Sanders, K., \& J. Jackson, C. (2018). Innovative behavior: how much transformational leadership do you need?. British Journal of Management, 29(4), 796-816.

Borisov, B., \& Stamenkova, L. P. (2020). the Role and Importance of Organizational Learning. 42(5), 889-893.

Galeazzo, A., \& Furlan, A. (2019). Good problem solvers? Leveraging knowledge sharing mechanisms and management support. Journal of Knowledge Management, 23(6), 1017-1038.

Guest, D., \& Conway, N. (2011). The impact of HR practices, HR effectiveness and a 'strong HR system' on organizational outcomes: a stakeholder perspective. International Journal of Human Resource Management, 22(8), 1686-1702.

Haris, M., Yao, H., Tariq, G., Malik, A., \& Javaid, H. (2019). Intellectual Capital Performance and Profitability of Banks: Evidence from Pakistan. Journal of Risk and Financial Management, 12(2), 56. https://doi.org/10.3390/jrfm12020056

Islam, T., \& Tariq, J. (2018). Learning organizational environment and extra-role behaviors: The mediating role of employee engagement. Journal of Management Development, 37(3), 258-270. https://doi.org/10.1108/JMD-01-2017-0039

Islamy, F., Yuniarsih, T., Ahman, E., \& Kusnendi, K. (2020). The role of organizational culture, knowledge sharing and job satisfaction in higher education. Management Science Letters, 10(16), 3957-3966.

Jamal, A. H., \& Tilchin, O. (2016). Teachers' Accountability for Adaptive Project-Based Learning. American Journal of Educational Research, 4(5), pp. 420-426.

Katou, A. A., \& Budhwar, P. S. (2010). Causal relationship between human resource management policies and organizational performance: Evidence from the Greek manufacturing sector. European Management Journal, 28, pp. 25-39.

Koeslag-Kreunen, M., Van den Bossche, P., Hoven, M., Van der Klink, M., \& Gijselaers, W. (2018). When leadership powers team learning: A meta-analysis. Small Group Research, 49(4), 475-513.

Marsick, V. J, \& Watkins, K. E. (2003). Demonstrating the value of an organization's learning culture: The dimensions of the learning organization questionnaire. Advances in Developing Human Resources, 5(2), pp. 132-51. 
Mthombeni, S., \& Niemand, L. (2019). Towards an Effective Learning Organization and the Role of Human Resources (HR) Department: The Case of a South African Finance Organization. Journal of Marketing and HR, 9(1), 536-553. http://www.scitecresearch.com/journals/index.php/jmhr/article/view/1691

Pandey, A., Gupta, V., \& Gupta, R. K. (2019). Spirituality and innovative behavior in teams: Examining the mediating role of team learning. IIMB Management Review, 31(2), 116-126. https://doi.org/10.1016/j.iimb.2019.03.013

Raes, E., Boon, A., Kyndt, E., \& Dochy, F. (2017). Exploring the occurrence of team learning behaviors in project teams over time. Research Papers in Education, 32(3), 376-401. https://doi.org/10.1080/02671522.2016.1225793

Raes, E., Decuyper, S., Lismont, B., Van den Bossche, P., Kyndt, E., Demeyere, S., \& Dochy, F. (2013). Facilitating team learning through transformational leadership. Instructional Science, 41(2), 287-305.

Ringle, C. M., Wende, S., \& Becker, J. (2015). SmartPLS 3. Bönningstedt: SmartPLS. Retrieved from http://www.smartpls.com

Rupčić, N. (2020). Learning organization - organization emerging from presence. In Learning Organization (Vol. 27, Issue 1, pp. 17-30). https://doi.org/10.1108/TLO-09-2019-0130

Sadq, Z., Othman, B., \& Mohammed, H. (2020). Attitudes of managers in the Iraqi Kurdistan region private banks towards the impact of knowledge management on organizational effectiveness. Management Science Letters, 10(8), $1835-1842$.

Schaubroeck, J., Carmeli, A., Bhatia, S., \& Paz, E. (2016). Enabling team learning when members are prone to contentious communication: The role of team leader coaching. human relations, 69(8), 1709-1727.

Schiavoni, F. L., de Faria, P. H., \& Manzolli, J. (2019). Interaction and collaboration in computer music using computer networks: An UbiMus perspective. Journal of new music research, 48(4), 316-330.

Tahernezhad, K., Sadaghiani, J., \& Ghaiyoomi, A. (2013). A study on relationship between organizational structure and learning characteristics: A case study of revenue agency. Management Science Letters, 3(3), 991-994.

Tan, F. Z., \& Olaore, G. O. (2021). Effect of organizational learning and effectiveness on the operations, employees productivity and management performance. Vilakshan - XIMB Journal of Management, ahead-of-print(ahead-of-print). https://doi.org/10.1108/xjm-09-2020-0122

Watzek, V., Anselmann, V., \& Mulder, R. H. (2019). Team learning and emotions during teamwork: a qualitative study. Research Papers in Education, 34(6), 769-789. https://doi.org/10.1080/02671522.2019.1568525

Werner, K., \& Dickson, G. (2018). Coworker knowledge sharing and peer learning among elite footballers: Insights from German Bundesliga players. Sport Management Review, 21(5), 596-611.

Zuo, L., Fisher, G. J., \& Yang, Z. (2019). Organizational learning and technological innovation: the distinct dimensions of novelty and meaningfulness that impact firm performance. Journal of the academy of marketing science, 47(6), 11661183. 
(C) 2022 by the authors; licensee Growing Science, Canada. This is an open access article distributed under the terms and conditions of the Creative Commons Attribution (CC-BY) license (http://creativecommons.org/licenses/by/4.0/). 